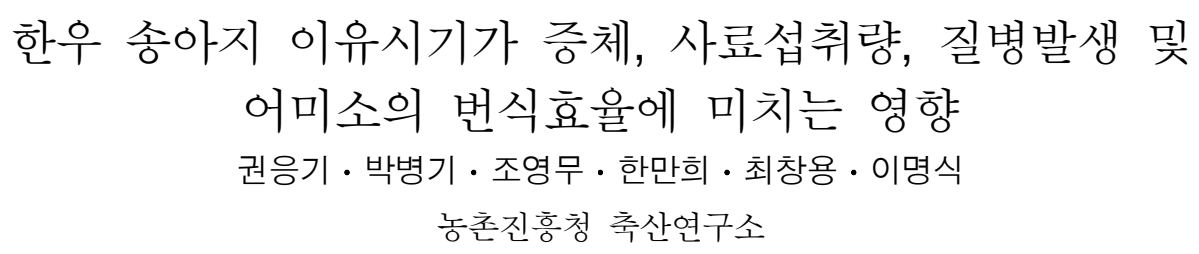

\title{
Effects of Weaning Age on Growth Performance, Feed Intake, Disease Occurrence of Hanwoo Calves and Reproductive Efficiency of Dams
}

\author{
E. G. Kwon, B. K. Park, Y. M. Cho, M. H. Han, C. Y. Choi and M. S. Lee
}

National Livestock Research Institute, R. D. A.

\begin{abstract}
This study was conducted to investigate effects of weaning age on growth perforance, feed intake, disease occurrence and maternal reproductive efficiency in Hanwoo. Sixty experimental calves were allocated into two groups, early weaned $(n=29$, calf age $90 \mathrm{~d}, \mathrm{EW})$ and normally weaned ( $\mathrm{n}=31$, calf age $120 \mathrm{~d}, \mathrm{NW})$. Body weights and average daily gains during nursing and post-weaning periods were similar between two groups ( $>0.05$ ). Weaning age had no effect on calf starter, grass hay, dry matter, crude protein and TDN intakes of calves ( $>0.05$ ). Maternal calving interval in EW was shortened by 23 days compared to NW ( $>0.05)$. Any difference in occurrence of disease was not observed between groups. Present results indicate that early weaning age has no negative effects on growth performance, feed intake or on disease occurrence in Hanwoo calves. And it has positive influence on maternal calving interval.
\end{abstract}

(Key words : Weaning age, Growth performance, Feed intake, Maternal reproductive efficiency, Hanwoo calf)

$$
\text { I. 서 론 }
$$

비육우와 암소의 생산성은 송아지의 분만간격 및 이유시기와 밀접한 관련이 있는데(Adams 등, 1994; Lusby 등, 1981), 농가 수익은 송아지의 이 유시기 조절과 암소의 번식효율 개선을 통해 향 상될 수 있다(Meyers 등, 1999; Whitter, 1995).

송아지 이유시기 단축의 장점으로는 성장률 (Peterson 등, 1987), 비육기 산육능력(Myers 등, 1999), 도체중(Makarechian 등, 1988) 및 도체품질 (Myers 등, 1999)을 개선시킨다는 보고가 있다.
그러나 일부 연구(Arthington 등, 2005 Lusby 등, 1981)에서는 송아지의 이유시기 단축이 증체와 건물섭취량에 미치는 영향이 없었다고 보고된 바 있다. 외국의 경우 사육조건에 따라 육우의 이 유 시기는 생후 0, 150, 210, 270 및 300일령 전후 로 다양하게 이루어지고 있는데, 이전의 연구결 과들에서 이유시기 조정에 따른 생산성의 일부 차이는 이유 일수의 차이에서 비롯되고 있다. 그 러나 중요한 사실은 생후 90 일령 조기이유가 비 육용 송아지의 생산성에 미치는 부의 영향은 없 을 뿐만 아니라 어미소의 번식효율 개선에도 긍

Corresponding author : E. G. Kwon, Hanwoo Experiment Station, National Livestock Research Institute, Chahang-Ri, Doam-Myon, Pyeongchang-Gun, Gangwon-Do, 232-952, Korea Tel: 033-330-0612, Fax: 033-330-0660, E-mail: kug2237@rda.go.kr 
정적인 영향을 미친다는 점이다(Green과 Buric, 령까지였다.

1953).

한편, 송아지의 이유시기와 어미소의 번식형 질과는 밀접한 관련이 있는데, 송아지의 이유시 기가 늦어질수록 어미소의 발정재귀일수는 길어 지는데(Short 등, 1972), Jung(1983)이 무각 Hereford 종 암소 450두를 조사한 결과 송아지를 포유 한 암소가 포유하지 않은 암소보다 분만에서 수 정까지의 기간이 길었다고 하여 송아지의 흡유 는 어미소의 번식형질과 부의 관계이므로 송아 지의 이유시기 단축은 어미소의 번식효율 개선 을 통한 농가 수익 증가가 가능하도록 할 수 있 다. 또한 Story 등(2000)은 이유시기 단축의 장점 으로서 생후 210 및 270일령 이유에 비해 생후 150 일령에 이유시킨 암송아지의 경우에는 첫 종 부전 체중이 높았고, 거세우의 경우에는 두당 순 수익이 향상되었다고 보고한 바 있다.

그러나 송아지의 이유시기와 관련된 증체와 사료섭취 능력은 육성률 향상과 더불어 어미소 의 번식효율 향상을 위해서도 매우 중요하게 고 려되어야 할 포유기 관리 기술임에도 불구하고, 지금까지 대부분의 한우 송아지에 관한 연구는 포유기 질병 조사와 관련된 연구(김 등, 1990; 서 등, 2001), 포유기 이후의 농후사료 급여수준에 따른 성장발육, 사료이용성 등의 효과 구명(강 등, 2003), 종모우군별 체중, 체장, 체고 등에 따른 생시 6개월령까지 송아지의 성장 효과(안 등, 1991) 위주로 수행되어서 이유시기와 관련된 생 산성 조사 연구는 미흡한 실정이다.

따라서 본 연구는 한우 송아지의 이유시기에 따른 발육, 사료섭취량, 질병발생 및 어미소의 번 식형질을 조사하여 우량 밑소의 육성률 향상과 암소의 번식효율 향상을 위한 기초자료 확보를 위하여 수행되었다.

\section{ㅍ. 재료 및 방법}

\section{1. 공시동물 및 시험기간}

본 연구에서 공시된 한우 송아지는 이유시기 별로 축산연구소에서 자체 생산된 한우 송아지 60 두였고, 시험기간은 포유기와 이유 후 12 개월

\section{2. 시험구 배치 및 사양관리}

시험구는 이유시기별로 조기이유 송아지 group(생후 3개월령 이유, 29두)과 관행이유 송아 지 group(생후 4개월령 이유, 31두)으로 구분하여 어미소와 함께 포유우리에 배치하였다. 포유우 리는 철근콘크리트 벽체의 철골구조 칼라강판 지붕 아래 전면에 사료조를 갖춘 구조였고, 이유 시기별로 각 우방에서 군사하였다(우방 크기, $4 \mathrm{~m} \times 12 \mathrm{~m})$. 조기이유 및 관행이유 group의 성별(우 $\left.=1, \delta^{\lambda}=2\right)$ 은 각각 $1.40 \pm 0.50$ 및 $1.55 \pm 0.51$ 이었다. 공시된 송아지 60 두는 포유기 동안에는 포유우 리내 별도의 케이지 $(2 \mathrm{~m} \times 2 \mathrm{~m})$ 를 이용하여 생후 10 일경부터 보조 사료인 인공유와 목건초 및 음수 를 자유섭취토록 하였으며, 이유 후 12 개월령까 지는 육성우사에서 축산연구소 관행사육에 따라 사양관리를 실시하였다. 시험사료의 성분은 Table 1 과 같다.

Table 1. Chemical composition of experimental feeds (as-fed basis)

\begin{tabular}{|c|c|c|}
\hline Items & Calf starter & Grass hay \\
\hline Dry matter (\%) & 87.68 & 89.33 \\
\hline Crude protein (\%) & 17.56 & 11.45 \\
\hline Ether extract (\%) & 3.02 & 1.66 \\
\hline Crude fiber (\%) & 6.12 & 29.98 \\
\hline Crude ash (\%) & 6.59 & 5.92 \\
\hline Calcium (\%) & 0.96 & 0.19 \\
\hline Phosphorus (\%) & 0.54 & 0.28 \\
\hline $\mathrm{TDN}^{1)}(\%)$ & 70.36 & 53.08 \\
\hline
\end{tabular}

1) TDN : Total digestible nutrients (calculated value).

\section{3. 조사항목 및 분석방법}

체중은 포유기(생시 이유시)에는 1 개월 간격 으로, 이유 후 육성기에는 6,12 개월령에 우형기 를 이용하여 측정한 후 일당증체량을 산출하였 으며, 포유기 사료섭취량은 매일 오전사료 급여 전(08:00h)에 사료잔량을 측정하여 산출하였다. 시험사료의 일반성분은 시험기간 동안 1 개월 간 격으로 시료를 채취하여 AOAC(1995) 방법에 준 
하여 분석하였다. 분만간격 일수 계산은 개체별 로 어미소의 차기 분만 일자에서 전 산차의 분만 일자를 감한 일수로 산정하였으며, 포유기 및 이 유 후 질병발생은 포유기 송아지에 다발하는 설 사, 호흡기 등을 중심으로 매일 기록하였다.

\section{4. 통계분석}

본 연구에서 얻어진 송아지 이유시기별 체중, 일당증체량 및 번식형질과의 비교는 SAS package(1999)를 이용하여 t-검정으로 두 집단 간 의 평균을 비교하여 유의성을 검증하였다.

\section{III. 결과 및 고찰}

한우 송아지의 이유시기별 포유기 및 이유 후 체중은 조기이유 송아지 group(early weaned calves; EW)과 관행이유 송아지 group(normally weaned claves NW)간 통계적 유의차는 없었다 ( $>0$ 0.05; Table 2). 조기이유 및 관행이유 송아지 의 생시 및 3 개월령 체중은 각각 24.3 vs 24.5 $\mathrm{kg}$ 및 $84.5 \mathrm{vs} 81.9 \mathrm{~kg}$ 이었다. 한편, $\mathrm{EW}$ 의 육 성기에 해당하는 생후 4, 6 및 12개월 체중은 각각 108.9, 153.3 및 $267.5 \mathrm{~kg}$ 이었고, $\mathrm{NW}$ 의 육성기에 해당하는 생후 6 및 12개월 체중은 각각 150.2 및 $270.7 \mathrm{~kg}$ 으로 두 시험구간 이유 후 육성기의 체중도 차이가 없었다 $(\mathrm{p}>0.05)$. 또 한 한우 송아지의 이유시기별 포유기 및 이유 후 일당증체량 역시 체중과 마찬가지로 $\mathrm{EW}$ 와

Table 2. Changes in growth performance by weaning age of Hanwoo calves

(unit : kg)

\begin{tabular}{crr}
\hline Month of age & \multicolumn{1}{c}{$\mathrm{EW}^{1)}$} & \multicolumn{1}{c}{$\mathrm{NW}^{2)}$} \\
\hline \hline 0 & $24.3 \pm 3.4$ & $24.5 \pm 3.0$ \\
1 & $40.9 \pm 6.8$ & $40.3 \pm 3.5$ \\
2 & $59.8 \pm 9.7$ & $59.4 \pm 5.3$ \\
3 & $84.5 \pm 13.2$ & $81.9 \pm 7.1$ \\
4 & $108.9 \pm 17.1$ & $107.0 \pm 12.2$ \\
6 & $153.3 \pm 25.5$ & $150.2 \pm 17.1$ \\
12 & $267.5 \pm 36.3$ & $270.7 \pm 32.4$ \\
\hline
\end{tabular}

\footnotetext{
1) EW: Calves were weaned at $90 \mathrm{~d}$ of age.

${ }^{2)} \mathrm{NW}$ : Calves were weaned at $120 \mathrm{~d}$ of age.
}

$\mathrm{NW}$ 간에 큰 차이가 없었는데( $\mathrm{p}>0.05)$, 생후 1 개 월령 일당증체량은 $0.51 \sim 0.56 \mathrm{~kg} / \mathrm{d}$ 에서 생후 4 개 월령에 $0.80 \sim 0.81 \mathrm{~kg} / \mathrm{d}$ 으로 증가하여 생후 12 개 월령에는 $0.71 \sim 0.72 \mathrm{~kg} / \mathrm{d}$ 을 유지하였다(Fig. 1).

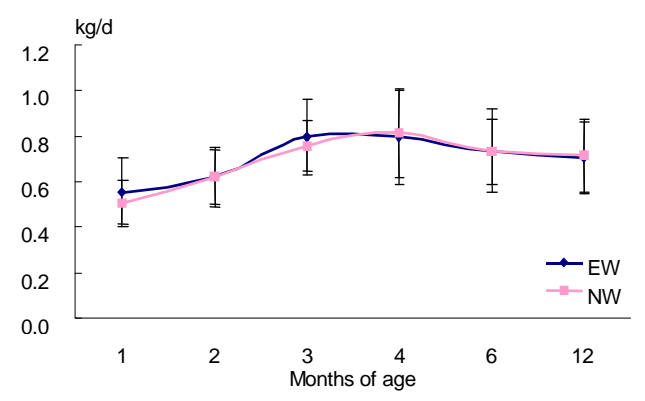

Fig. 1. Changes in average daily gain by weaning age of Hanwoo calves.

예상대로 한우 송아지의 이유시기 조정은 포 유기 및 이유후 성장발육에 영향을 미치지 않았기 때문에 출생 직후 초유 섭취 유도를 철저히 하고 어미소의 포유와 함께 반추위 발달을 위한 고형 사료의 적절한 공급이 이루어진다면 어미소의 포유는 생후 90 일 정도면 충분한 것으로 판단된다. 따라서 본 연구의 결과는 현재 농가의 사정에 따라 생후 4 6개월령까지 관행적으로 이루어지 고 있는 이유시기를 생후 3개월령 이전까지도 단 축시킬 수 있다는 가능성을 시사하는 것으로 사 료된다. 또한 본 연구에서 나타난 결과는 이유시 기 단축이 송아지의 발육에 영향을 미치지 않았 다는 이전의 연구결과(Arthington 등, 2005; Lusby 등, 1981)와 비슷하였으며, 생후 90, 152 및 215일 에 이유시킨 교잡종 거세우들의 일당증체량의 차이가 없었다는 Myers 등(1999)의 연구결과와 도 유사하였다.

인공유, 목건초, 건물, 조단백질 및 TDN 섭취 량과 음수량은 두 시험구간에 차이가 없었으며 ( $>0.05$; Table 3), 송아지의 생후 일령이 경과할 수록 이들 섭취량이 비례적으로 증가하는 경향 이었다. 인공유 섭취량은 생후 30 일 이전에 비해 생후 31 60일경에 4배 이상 증가하였으며, 건물, 조단백질 및 $\mathrm{TDN}$ 섭취량도 인공유 섭취량과 유 사한 경향을 보였다. 목건초 섭취량은 생후 31 60일경에 비해 생후 61 90일경에 크게 증가 하는 경향을 보였다. 
Table 3. Changes in feed, water and nutrient intakes by weaning age of Hanwoo calves

\begin{tabular}{|c|c|c|c|}
\hline Item & Days of age & $\mathrm{EW}$ & NW \\
\hline Claf starter (g) & $\begin{aligned} & \leq 30 \\
& 31 \sim 60 \\
& 61 \sim 90 \\
& 91 \sim 120 \\
&\end{aligned}$ & $\begin{aligned} 65.86 & \pm 57.12 \\
278.58 & \pm 152.28 \\
1,009.31 & \pm 389.49 \\
& -\end{aligned}$ & $\begin{array}{r}62.18 \pm 90.41 \\
283.03 \pm 155.54 \\
997.62 \pm 412.84 \\
2,124.32 \pm 563.10\end{array}$ \\
\hline Grass hay (g) & $\begin{aligned} & \leq 30 \\
31 & \sim 60 \\
61 & \sim 90 \\
91 & \sim 120\end{aligned}$ & $\begin{array}{c}199.41 \pm 170.19 \\
287.38 \pm 111.07 \\
545.84 \pm 203.32 \\
-\end{array}$ & $\begin{array}{r}210.83 \pm 96.23 \\
295.38 \pm 112.01 \\
552.00 \pm 201.25 \\
1,087.17 \pm 469.61\end{array}$ \\
\hline Dry matter (g) & $\begin{aligned} & \leq 30 \\
31 & \sim 60 \\
61 & \sim 90 \\
91 & \sim 120\end{aligned}$ & $\begin{aligned} 271.29 & \pm 174.42 \\
566.80 & \pm 221.01 \\
1,555.14 & \pm 524.02 \\
& -\end{aligned}$ & $\begin{array}{r}276.87 \pm 115.81 \\
578.41 \pm 222.96 \\
1,549.62 \pm 527.98 \\
3,211.49 \pm 870.66 \\
\end{array}$ \\
\hline Crude protein (g) & $\begin{aligned} & \leq 30 \\
31 & \sim 60 \\
61 & \sim 90 \\
91 & \sim 120\end{aligned}$ & $\begin{array}{rr}32.45 \pm & 17.95 \\
79.55 & \pm 33.84 \\
236.55 \pm & 81.42 \\
- & \end{array}$ & $\begin{array}{r}32.81 \pm 17.72 \\
81.12 \pm 33.98 \\
235.27 \pm 83.75 \\
488.43 \pm 127.24 \\
\end{array}$ \\
\hline TDN (g) & $\begin{aligned} & \leq 30 \\
& 31 \sim 60 \\
& 61 \sim 90 \\
& 91 \sim 120 \\
&\end{aligned}$ & $\begin{array}{r}157.10 \pm 95.85 \\
351.46 \pm 141.93 \\
1,005.22 \pm 343.95 \\
- \\
\end{array}$ & $\begin{array}{r}159.47 \pm 72.42 \\
358.45 \pm 143.44 \\
1,000.30 \pm 349.51 \\
2,082.54 \pm 552.30 \\
\end{array}$ \\
\hline
\end{tabular}

따라서 본 연구의 결과에서 한우 송아지 이유 시기별 두 시험구간 사료섭취량의 차이는 없었 고, 생후 3개월령 성장발육(Table 2 및 Fig. 1)의 차이도 없는 것으로 나타나 한우 송아지의 인공 유와 목건초 섭취량이 각각 1,000 및 $550 \mathrm{~g}$ 전후 수준으로 도달하는 생후 90 일(3개월령)에 송아지 를 이유시키는 것이 바람직할 것으로 사료된다. 또한 본 연구에서는 한우 송아지의 이유 후 육성 기 사료섭취량 조사가 이루어지지는 않았으나, 일반적으로 송아지의 이유시기가 늦어질수록 육 성기 비육기 동안 사료섭취량은 많아지고 사료 효율은 낮아지기 때문에(Arthington 등, 2005; Myers 등, 1999) 한우 송아지의 이유 후 육성기 및 비육기 동안 사료이용성의 측면에서도 이유시기 를 앞당기는 것이 바람직 할 것으로 사료된다.

한우 송아지의 이유시기 조정이 어미소의 발정 재귀일수에 미치는 영향은 없었으나(p>0.05; 40.9 vs 41.2 일), 분만간격은 $\mathrm{NW}$ 에 비해 $\mathrm{EW}$ 에서 23일 정도 단축되는 경향이었다(p>0.05; 370.0 vs 392.8 일 Fig. 2).

본 연구에서 나타난 결과는 송아지의 이유시 기 단축이 어미소의 분만-수태 간격을 짧게 하 고 수태율을 개선시킨다는 Myers 등(1999)의 연 구결과와 유사하였을 뿐만 아니라 무각 Hereford
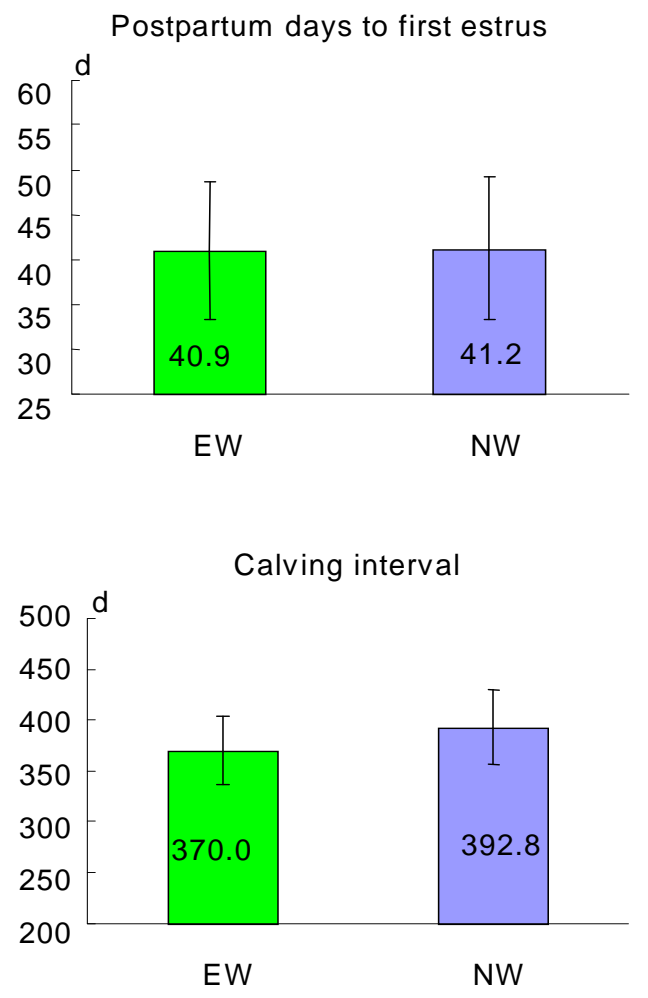

Fig. 2. Changes in maternal postpartum days to first estrus and calving interval by weaning age of Hanwoo calves. 
암소 450두를 조사한 결과 송아지를 포유하지 않 은 암소는 송아지를 포유한 암소에 비해 분만-임 신 간격이 짧았다는 Jung(1983)의 결과와도 비슷 한 것으로 판단된다.

따라서 송아지 포유와 관련된 어미소의 모성 본능(maternal behavior)은 수태당 종부횟수와 분 만간격 증가 등 어미소의 번식기능의 회복에 부 의 효과를 나타내기 때문에(Hoffman 등, 1996 Williams 등, 1993) 송아지 이유시기를 성장(Table 2 및 Fig. 1)과 영양소 섭취량(Table 3)을 고려하여 적절하게 단축시킴으로서 어미소의 번식효율을 향상시킬 수 있을 것으로 판단된다. 또한 한우 송 아지 이유시기 조정은 번식우 사육농가의 목표 인 매년 송아지 생산을 가능하게 하는데 도움이 될 뿐만 아니라 경영비 절감을 통한 생산성 향상 도 가능할 것으로 사료된다.

일반적으로 모유 의존도가 높은 생후 30 일경 까지의 신생 송아지는 출생 직후 환경 적응능력 이 떨어지고 사육환경 관련 스트레스까지 겹치 게 되면 비감염성 설사에 노출되기 쉽고, 체온조 절, 소화양식, 장내세균총 형성의 미숙, 에너지원 의 전환, 당의 신생 등 여러 가지 변화를 격게 된 다(Jain, 1986; 이 등, 1995). 또한 Martin과 Wiggins(1973)은 소화기 질병의 경우 생후 2주 이내 에 발병하여 증체에 영향을 주고, 설사는 송아지 폐사의 가장 중요한 원인중의 하나로써 병원성 미생물, 사육환경 및 송아지 자체의 면역학적, 영 양학적 요인 등의 상호작용으로 발생된다고 보 고한 바 있다.

포유기에 주로 발생하는 질병은 호흡기질병과

Table 4. Changes in disease occurrences by weaning age of Hanwoo calves

(unit : head)

\begin{tabular}{lcccccc}
\hline \multirow{2}{*}{ Diseases } & \multicolumn{5}{c}{ Days of age } & \multirow{2}{*}{$\%$} \\
\cline { 2 - 7 } & & $\leq 30$ & $31 \sim 60$ & $61 \sim 90$ & $91 \sim 180$ & \\
\hline \hline \multirow{2}{*}{$\begin{array}{l}\text { Respi- } \\
\text { ratory }\end{array}$} & EW & 1 & - & - & - & 3.45 \\
\hline \multirow{2}{*}{ Diarrhea } & EW & 2 & 1 & - & - & 10.34 \\
& NW & 1 & 3 & 1 & - & 16.13 \\
\hline \multirow{2}{*}{ Others } & EW & 1 & - & - & - & 3.45 \\
& NW & - & - & - & - & - \\
\hline \multicolumn{2}{c}{ Total } & 5 & 5 & 1 & - & 18.33 \\
\hline
\end{tabular}

설사로서 송아지의 이유시기와는 관계없이 주로 생후 60 일 이내에서 호흡기질병과 설사가 발병 하였는데(Table 4), 본 연구의 결과는 교잡종 송 아지 168 두의 이유시기별(생후 90, 152 및 215일) 질병 발생 조사에서 이유시기가 송아지의 질병 발생률 변화에 영향을 미치지 않았다는 Myers 등 (1999)의 결과와 일치하였다. 또한 한우 송아지 268두를 대상으로 질병발생 여부를 조사한 결과 발생된 질병의 유형별로는 소화기질병이 $54.1 \%$ 로 가장 많고, 소화기질병과 호흡기질병의 혼합 감염이 $21.6 \%$, 호흡기 질병이 $14.5 \%$ 순이었다는 권 등(2000)의 결과와 포유기 한우 송아지 211두 중 $97.6 \%$ 가 생후 84 일 이전에 1 회 이상 설사가 발 생하였다는 김 등(1990)의 결과와도 비슷한 것으 로 사료된다.

따라서 한우 송아지 이유시기를 단축함으로서 어미소와 합사로 인해 유발될 수 있는 사육환경 불량 등으로 인한 설사, 호흡기질병 등의 송아지 질병 발생을 경감시킬 수 있고, 어미소의 분만간 격 단축으로 경영비 절감도 가능할 것으로 판단 된다.

$$
\text { V. 요 약 }
$$

본 연구는 한우 송아지의 이유시기별 발육, 사 료섭취량, 질병발생 및 어미소의 번식효율에 미 치는 영향을 조사하기 위하여 수행되었다. 시험 축은 축산연구소에서 자체 생산된 한우 송아지 60 두를 공시하여 이유시기별로 조기이유 $(\mathrm{EW}$, 생 후 3 개월령)와 관행이유(NW, 생후 4 개월령)에 각 각 29 및 31두씩 배치하여 두 개의 시험구를 두었 다. 송아지의 포유기 및 이유후 체중과 일당증체 량은 이유시기에 따른 차이는 없었다 $(\mathrm{p}>0.05)$. 또 한 인공유, 목건초, 건물, 조단백질 및 TDN 섭취 량도 이유시기에 의한 영향은 없었다( $>>0.05)$. 어 미소의 분만간격은 관행이유 시험구에 비해 조 기이유 시험구에서 23일 정도 단축되는 경향을 보였다(p>0.05). 한편 이유시기에 따른 발생 질병 의 종류와 발병율은 시험구간 차이가 없는 것으 로 조사되었다. 따라서 이유시기 단축이 한우 송 아지의 성장, 사료섭취량 및 질병 발생에 미치는 부의 영향은 없었을 뿐만 아니라 어미소의 분만 
간격을 단축시키는데 효과가 있는 것으로 사료 된다.

\section{$\mathrm{V}$. 인 용 문 헌}

1. Adams, E. C., Clark, R. T., Coady, S. A., Lamb, J. B. and Nielsen, M. K. 1994. Extended grazing systems for improving economic returns from Nebraska sandhills cow / calf operations. J. Range Manage. 47:258-263.

2. AOAC. 1995. Official Methods of Analysis. $16^{\text {th }}$ Ed. Association of Official Analytical Chemist, Washington D. C., U. S. A.

3. Arthington, J. D., Spears, J. W. and Miller, D. C. 2005. The effect of early weaning on feedlot performance and measures of stress in beef calves. J. Anim. Sci. 83:933-939.

4. Green, W. W. and Buric, J. 1953. Comparative performance of beef calves weaned at 90 and 180 days of age. J. Anim. Sci. 12:561-572.

5. Hoffman, D. P., Stevenson, J. S. and Minton, J. E. 1996. Restricting calf presence without suckling compared with weaning prolongs postpartum anovulation in beef cattle. J. Anim. Sci. 74:190198.

6. Jain, N. C. 1986. Cattle : Normal hematology with comments on response to disease. In : Schalm's veterinary hematology. $4^{\text {th }}$. 2 d, Lea \& Febiger. pp. 178-207.

7. Jung, J. K. 1983. Effects of calving date, cow age and suckling on the interval from calving to conception in beef cows. Kor. J. Anim. Sci. 25:470-475.

8. Lusby, K. S., Wettemann, R. P. and Turman, E. J. 1981. Effects of early weaning calves from first-calf heifers on calf and heifer performance. J. Anim. Sci. 53:1193-1197.

9. Makarechian, M., Kubisch, H. M. and Price, M. A. 1988. Effects of date of weaning on subsequent performance of beef cows and their female calves. Can. J. Anim. Sci. 68:1035-1040.

10. Martin, S. W. and Wiggins, A. D. 1973. A model of the economic costs of dairy calf mortality. Am. J. Vet. 34:1027-1031.

11. Myers, S. E., Faulkner, D. B., Ireland, F. A. and Parrett, D. F. 1999. Comparison of three weaning ages on cow-calf performance and steer carcass traits. J. Anim. Sci. 77:323-329.

12. Peterson, G. A., Turner, T. B., Irvin, K. M., Davis, M. E., Newland, H. W. and Harvey, W. R. 1987. Cow and calf performance and economic considerations of early weaning of fall-born beef calves. J. Anim. Sci. 64:15-22.

13. SAS. 1999. SAS/STAT Software for PC. Release 6.11, SAS Institute, Cary, NC, U. S. A.

14. Short, R. E., Bellows, R. A., Moody, E. L. and Howland, B. E. 1972. Effects of suckling and mastectomy on bovine postpartum reproduction. J. Anim. Sci. 34:70-74.

15. Story, C. E., Rasby, R. J., Clark, R. T. and Milton, C. T. 2000. Age of calf at weaning of spring-calving beef cows and the effect on cow and calf performance and production economics. J. Anim. Sci. 78:1403-1413.

16. Whitter, J. 1995. Time of weaning and cow condition. In: Proc., The Range Beef Cow Symposium X IV, Gering, NE. pp. 92-104.

17. Williams, G. L., McVey, W. R. Jr. and Hunter, J. F. 1993. Mammary somatosensory pathways are not required for suckling-mediated inhibition of luteinizing hormone secretion and delay of ovulation in cows. Biol. Reprod. 49:1328-1337.

18. 강수원, 임석기, 정종원, 우제석, 전기준. 2003. 농 후사료 급여수준 및 방목이 춘계분만 한우 암송 아지의 성장발육, 번식능력 및 사료이용성에 미 치는 효과. 한국동물자원과학회지. 45:101-112.

19. 권오덕, 최경성, 이승옥, 정환, 이주목. 2000. 한우 신생송아지의 질병발생에 관한 조사연구. 한국임 상수의학회지. 17:93-101.

20. 김 두, 유영수, 유한상, 윤충근. 1990. 한우 송아 지의 포유기간 중의 설사발생에 관한 연구. 대한 수의학회지. 30:255-260.

21. 서국현, 이동원, 허태영, 류일선, 손동수, 정영훈, 최창용, 김일화. 2001. 송아지 수동면역 결핍과 질병발생에 관한 요인 연구. 축산시험연구보고서. pp. 406-433.

22. 안병석, 김영근, 한학석, 박태진. 1991. 한우 송아 지의 성장에 미치는 종모우군의 효과. 한국축산 학회지. 33:646-650.

23. 이현범, 권오덕, 강정부, 윤종삼. 가축질병학(총론. 우병학). 1995. 유한문화사. pp. 83-95.

(접수일자 : 2007. 2. 16. / 채택일자 : 2007. 4. 9.) 